\title{
An amblyopinine rove beetle (Coleoptera, Staphylinidae, Staphylininae, Amblyopinini) from the earliest Miocene Foulden Maar fossil-Lagerstätte, New Zealand
}

\author{
Josh Jenkins Shaw, ${ }^{1}$ (i) Alexey Solodovnikov, ${ }^{2}$ Ming Bai, ${ }^{1 *}$ and Uwe Kaulfuss ${ }^{3}$ \\ ${ }^{1}$ Key Laboratory of Zoological Systematics and Evolution, Institute of Zoology, Chinese Academy of Sciences, Beijing, 100101, China \\ $<$ joshjenkins@btinternet.com><baim@ioz.ac.cn> \\ ${ }^{2}$ Natural History Museum of Denmark, Zoological Museum, Universitetsparken 15, Copenhagen 2100, Denmark <asolodovnikov@snm.ku.dk> \\ ${ }^{3}$ Department of Animal Evolution and Biodiversity, University of Göttingen, Germany <uwe.kaulfuss@ uni-goettingen.de>
}

\begin{abstract}
The first fossil rove beetle (Coleoptera, Staphylinidae) from New Zealand is described from the earliest Miocene Foulden Maar fossil-Lagerstätte, Otago. The new species, Sphingoquedius meto n. sp., is attributable to the tribe Amblyopinini of the subfamily Staphylininae based on the scutellum with anterior scutellar ridge only; isodiametric microsculpture on the pronotum; multidirectional arranged setae on the elytra; and presence of radiating setae on the fourth abdominal tergite. Sphingoquedius meto n. sp. is the first Southern Hemisphere fossil record of Amblyopinini and its affinity to the extant fauna as well as biogeographic and paleocological implications are discussed.
\end{abstract}

UUID: http://zoobank.org/52275b83-d5ff-48af-A66F-2d62c3461677

\section{Introduction}

In the global context $(64,031$ described species of rove beetles according to Newton, 2019), the New Zealand rove beetle fauna is significant and peculiar. It accounts for 936 native species with $>90 \%$ of them being endemic, including some undescribed species, as estimated by Klimaszewski et al. (1996). Particularly notable for the native New Zealand fauna is the absence of many major rove beetle lineages that are otherwise widespread elsewhere, for example the subtribe Philonthina of the tribe Staphylinini (Solodovnikov and Brunke, 2016). Equally as notable is the presence of several rove beetle groups that underwent extensive species radiation there, some of which exhibit disjunct distributions on the continents that once formed Gondwana, or were connected afterwards, such as, for example, the South America-Australia connection via Antarctica. One such example is the tribe Amblyopinini of the subfamily Staphylininae, which are extremely diverse in Australia, New Guinea, New Caledonia, New Zealand, and South America, and form several clades consisting of species from these different landmasses (Jenkins Shaw et al., 2020). After being considered as a subtribe of the tribe Staphylinini, Amblyopinini were recently returned to tribe status in the course of a broader phylogenetic study and reclassification of the subfamily Staphylininae (Żyła and Solodovnikov, 2020). Very soon after, Tihelka et al. (2020) reinstated them as a subtribe Amblyopinina of the tribe Staphylinini in a study that did not show significant phylogenetic conflict with Żyła and Solodovnikov (2020), even though it claimed so. The disagreement between Żyła and

\footnotetext{
*Corresponding author
}

Solodovnikov (2020) and Tihelka et al. (2020) mainly concerns the taxonomic interpretation of the largely similar phylogenetic pattern. Here we follow the classification of Żyła and Solodovnikov (2020), which seems to us better justified, especially with regard to the tribal status of Amblyopinini. In New Zealand the tribe is represented by 54 described species with an estimated 30 + species awaiting description (Solodovnikov and Brunke, 2016; Solodovnikov, unpublished data). As estimated in the molecular phylogeny of Jenkins Shaw et al. (2020), the New Zealand amblyopinines form several lineages with species mainly from Australia, including Tasmania and South America (Jenkins Shaw et al., 2020, p. 438, fig. 4, clades F2-F5). This phylogenetic pattern is not translated into new classification yet - the majority of described species of New Zealand and Australian amblyopinines are still incorrectly placed in the genus Quedius Stephens, 1829, which, according to phylogenetic studies (Solodovnikov, 2006; Brunke et al., 2016; Cai et al., 2019; Jenkins Shaw et al., 2020; Tihelka et al., 2020; Żyła and Solodovnikov, 2020) is a north temperate group from a different tribe Quediini. The large/diverse fauna of the tribe Amblyopinini, including that of New Zealand, awaits generic reclassification (Jenkins Shaw et al., 2020). In New Zealand, only a small number of morphologically derived species have been described as new genera by earlier authors. Of them, the genus Sphingoquedius Bernhauer, 1941, currently including two species, $S$. strandi Bernhauer, 1941 and S. novaezeelandiae (Duvivier, 1883) (Solodovnikov and Brunke, 2016), certainly will accommodate a substantial chunk of New Zealand amblyopinines based on the currently available phylogenetic data.

Despite having what is presumed to be a relatively long evolutionary history, amblyopinines are poorly represented in the fossil record, with just three species described, all from the 
Table 1. Described Amblyopinini fossils.

\begin{tabular}{|c|c|c|c|c|}
\hline Species & Author & Locality & Horizon & Preservation \\
\hline Heterothops conticens* & Scudder, 1900 & $\begin{array}{l}\text { Florissant } \\
\text { Formation, Colorado, U.S.A. }\end{array}$ & Early Eocene & Compression \\
\hline Sphingoquedius meto $\mathrm{n}$. sp. & Jenkins Shaw and Solodovnikov, 2020 & Foulden Maar Fossil-Lagerstätte, New Zealand & Earliest Miocene & Compression \\
\hline Heterothops cornelli & Chatzimanolis and Engel, 2013 & Dominican Republic & Oligo-Miocene & Amber inclusion \\
\hline Heterothops infernalis & Chatzimanolis and Engel, 2013 & Dominican Republic & Oligo-Miocene & Amber inclusion \\
\hline
\end{tabular}

*Placement in the genus considered doubtful (Jenkins Shaw et al., 2020)

wide-spread genus Heterothops Stephens, 1829 (Table 1). Two species are described from Dominican amber (Chatzimanolis and Engel, 2013) and one (doubtful) from the Florissant Formation, Colorado, U.S.A. (Scudder, 1900). Therefore, any new fossils of this group are of great interest, especially from the Southern Hemisphere, where the rove beetle fossil record became the subject of research only very recently (Schomann and Solodovnikov, 2012; Cai et al., 2013, 2015).

Here, we describe Sphingoquedius meto new species (Figs. 1, 2.1) as the first rove beetle from the Foulden Maar fossil-Lagerstätte, New Zealand. The beetle is assigned to the tribe Amblyopinini of the subfamily Staphylininae and compared to extant members of that diverse, biogeographically interesting tribe. The paleocological significance of this fossil is discussed.

\section{Geological setting}

The Foulden Maar fossil-Lagerstätte in southern New Zealand provides an opportunity to contribute to the study of numerous arthropod groups and to reconstruct an earliest Miocene Southern Hemisphere mid-latitude lake/forest ecosystem (Lee et al., 2016). The Foulden Maar is a partly eroded maar-diatreme volcano of the Waipiata Volcanic Field, Otago, which erupted in the latest Oligocene at $23.2 \mathrm{Ma}$ (Lindqvist and Lee, 2009). The maar crater is filled by a $\sim 190 \mathrm{~m}$ thick sequence of lacustrine mass-flow sediments and highly fossiliferous diatomite, which represents a depositional period of ca. 130,000 years and spans the Oligocene/Miocene boundary (Fox et al., 2015; Kaulfuss, 2017). A macro- and microflora, fish, and numerous arthropods (insects and spiders) excavated from the uppermost $10 \mathrm{~m}$ of the diatomite are considered to be of earliest Miocene age (Mildenhall et al., 2014; Lee et al., 2016). In an overview of the fossil arthropod fauna from this site, Kaulfuss et al. (2015) mentioned several coleopteran families, including at least two rove beetle genera, one in the subfamily Osoriinae and the other a possible Pselaphinae, which so far remain undescribed.

Locality information.-Foulden Maar diatomite, earliest Miocene, near Middlemarch, Otago, New Zealand (45.5269 S, $170.2191^{\circ}$ E; New Zealand Fossil Record File I43/f8503).

\section{Materials and methods}

The fossil is an incompletely preserved dorsal compression, therefore ventral characters are not visible (Fig. 1.1). The head and prothorax are apparently directed left and downwards. Only the left presumed mesotibiae and tarsomeres are preserved
(Fig. 1). The left antenna is completely preserved, the right antenna is represented by antennomeres $1-8$.

The fossil was prepared using fine needles and paint brushes, and photographed under ethanol with a Canon T3 camera attached to a Nikon SMZ1000 stereomicroscope. Photomicrographs taken at several depths of field were stacked using Photoshop CS5.1 software (Adobe Systems Inc.).

Measurements were taken using ImageJ (Schneider et al., 2012) and are given in millimeters (mm). The following measurements were taken: TL (total body length from apex of frons to apex of abdominal segment X); EL (elytral length from apex of scutellum to posterior inner edge of elytra); HL (head length from frons to nuchal ridge); AL (antennae length)

Repository and institutional abbreviation.-The type material is deposited in the Museum of the Geology Department, University of Otago (OU), New Zealand.

\section{Systematic paleontology}

Order Coleoptera Linnaeus, 1758

Family Staphylinindae Latreille, 1802

Subfamily Staphylininae Latreille, 1802

Tribe Amblyopinini Seevers, 1944

Genus Sphingoquedius Bernhauer, 1941

Type species: Sphingoquedius strandi Bernhauer, 1941

Sphingoquedius meto new species

Figures 1-2.1

Holotype.-OU46635. Male(?). Foulden Maar, early Miocene $(23.2 \pm 0.2 \mathrm{Ma})$, near Middlemarch, Otago, New Zealand.

Diagnosis.—Among all species of Amblyopinini, including two extant species that are currently formally in this genus, Sphingoquedius meto $\mathrm{n}$. $\mathrm{sp}$. can be diagnosed by a combination of the rather large eyes, distinct isodiametric microsculpture of the pronotum (Figs. 1, 2.1), elytra with variegate (arranged multidirectionally) setae, abdominal tergite III with posterior basal transverse carina, abdominal tergite IV with patch of radiating setae, and abdominal tergite VI with medially sinuate anterior basal transverse carina (Fig. 1).

Occurrence.-Foulden Maar diatomite, earliest Miocene, near Middlemarch, Otago, New Zealand $\left(45.5269^{\circ} \mathrm{S}, 170.2191^{\circ} \mathrm{E}\right.$; New Zealand Fossil Record File I43/f8503). 

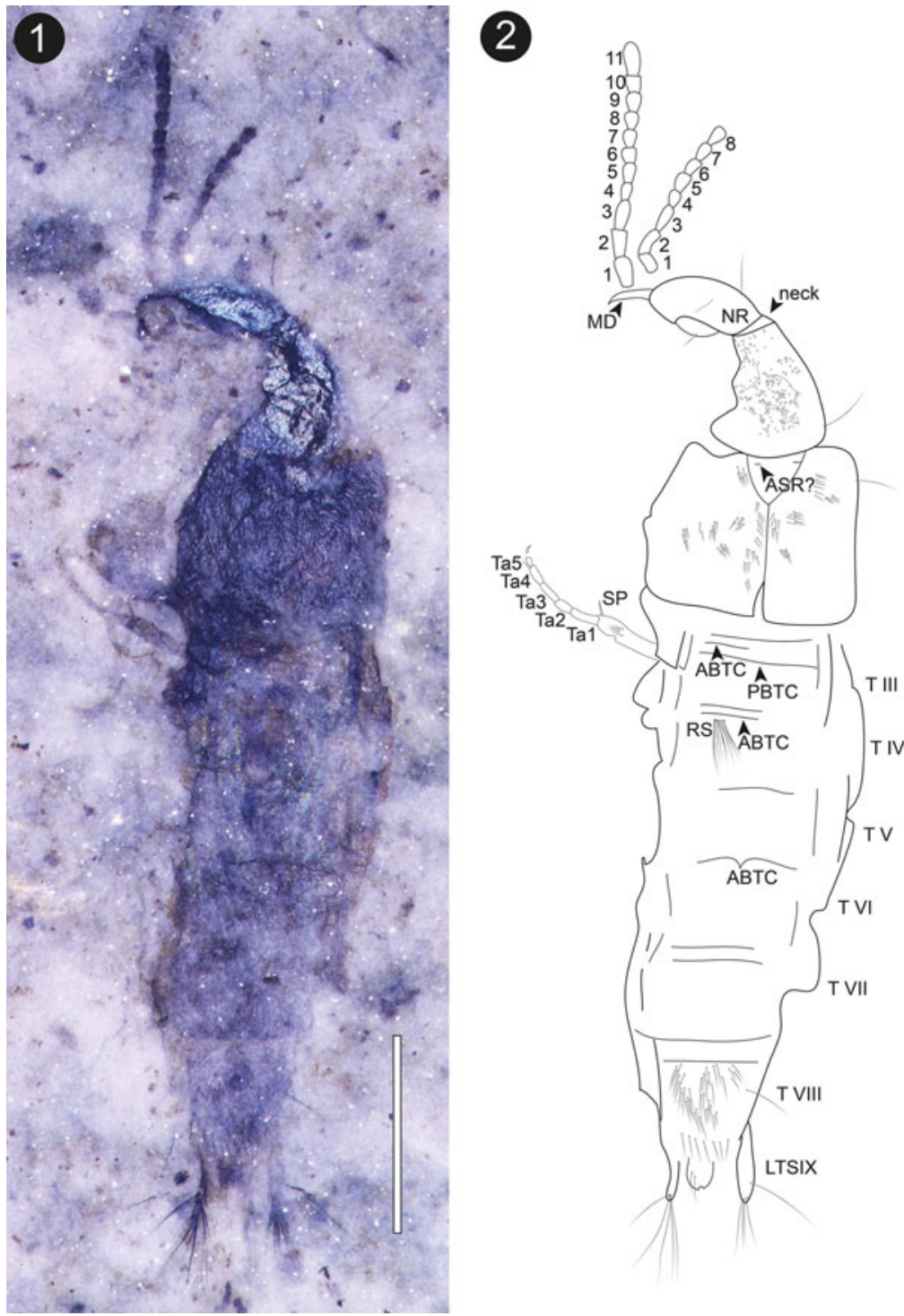

Figure 1. (1) Photograph of the holotype OU46635 of Sphingoquedius meto n. sp. (2) Reconstructed line drawing of the holotype OU46635 of Sphingoquedius meto $\mathrm{n}$. sp. $\mathrm{ABTC}=$ anterior basal transverse carina, $\mathrm{ASR}=$ anterior scutellar ridge, $\mathrm{LTSIX}=$ lateral tergal sclerites $\mathrm{X}, \mathrm{MD}=$ mandibles, $\mathrm{NR}=$ nuchal ridge, $\mathrm{PBTC}=$ Posterior basal transverse carina, $\mathrm{RS}=$ radiating setae, $\mathrm{SP}=$ spur, $\mathrm{Ta}=$ tarsomeres, $\mathrm{T}=$ tergites. Antennomeres are numbered $1-8$ (right antenna) and $1-11$ (left antenna). Scale bar $=1.0 \mathrm{~mm}$.

Description.-Medium-sized rove beetle, characteristically elongate. Elytra approximately quadrate. Abdomen elongate, tapering to the end. Measurements: $\mathrm{TL}=5 \mathrm{~mm} ; \mathrm{EL}=0.6 \mathrm{~mm}$, $\mathrm{HL}=0.48 \mathrm{~mm}, \mathrm{AL}=1.24 \mathrm{~mm}$.

Head apparently rather elongate, appearing to have a metallic shimmer; eyes, as far as discernable, occupying approximately half of head length. Nuchal ridge present dorsally (Fig. 1.2, NR). Antennae 11 segmented: all antennomeres elongate, except antennomeres 5-7, about as long as wide each. Antennomere 11 approximately twice as long as wide. Mandible(s) relatively long, acutely pointed apically (Fig. 1.2, MD).

Pronotum, with broadly rounded, indistinct hind angles, appearing somewhat metallic, with distinct isodiametric microsculpture (Figs. 1.1, 2.1).

Elytra as long as wide. Scutellum apparently with anterior scutellar ridge only (Fig. 1.2, ASR); unpunctured, except for some apparent setae in the posterior third. Elytral humerus rounded, without spines. Side of elytra with long macro setae in anterior quarter. Elytra with dense multidirectionally arranged (variegate) setation.

Abdomen (Fig. 1.2, T III to T VIII, LTSIX) tergites III to VII each with two pairs of paratergites. Tergite III with anterior and posterior basal transverse carinae (Fig. 1.2, ABTC, PBTC). Tergite IV with anterior basal transverse carina (Fig. 1.2, ABTC) and probably a pair of patches of long radiating setae (preserved on one side of tergite; Fig. 1.2, RS). Anterior basal transverse carina of tergite VI sinuate medially. Tergite VIII with medium-long radiated setae on surface and row of longer setae along apical margin. Apical portion of tergite $\mathrm{X}$ rounded and setose. Lateral tergal sclerites IX relatively long, inflated, with apical clusters of numerous strong and long setae (Fig. 1.2, LTSIX). 

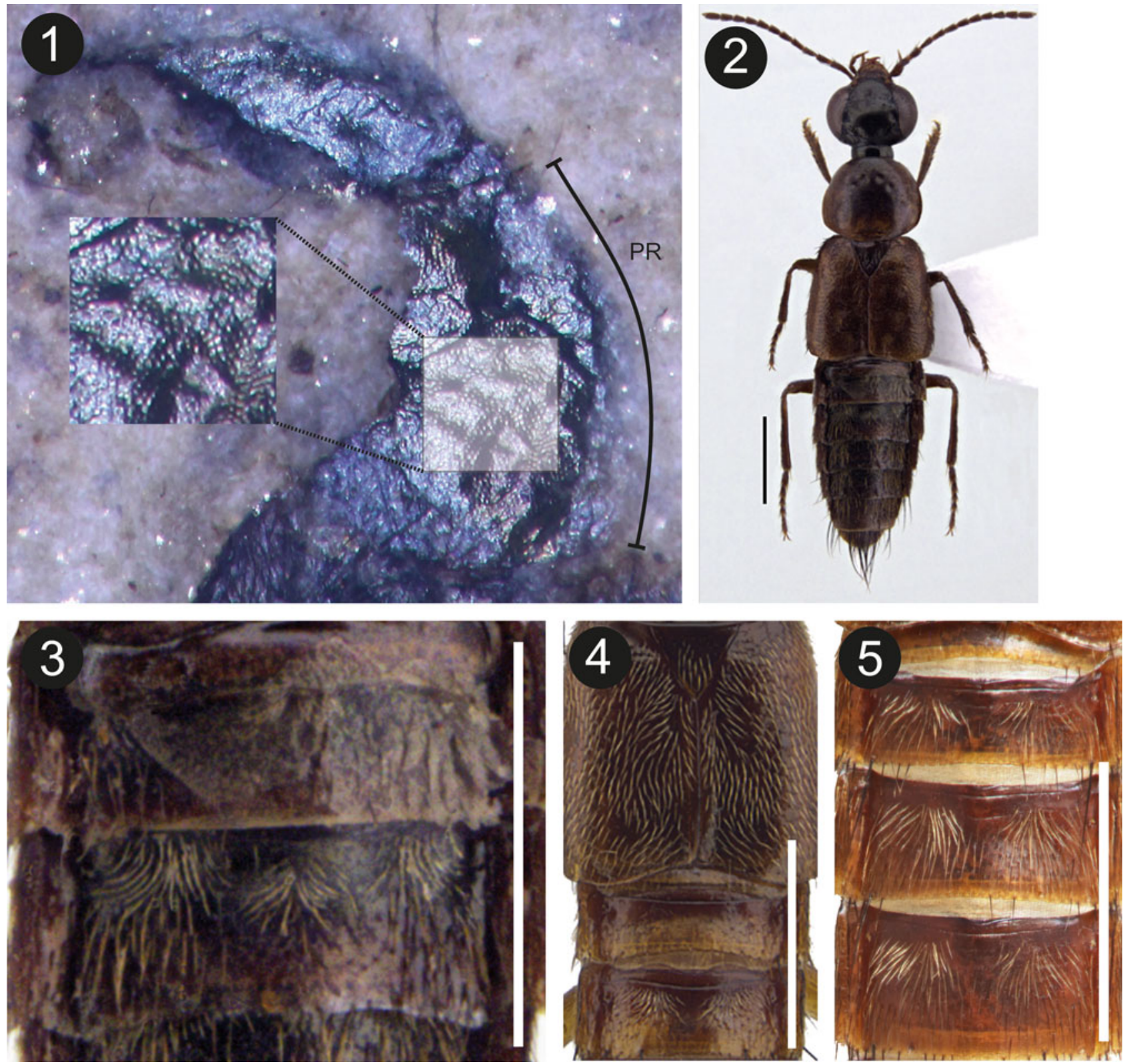

Figure 2. (1) Holotype OU46635 of Sphingoquedius meto n. sp.: head and pronotum, close up of microsculpture (inset). (2, 3) Sphingoquedius strandi Bernhauer, 1941: habitus (2); close-up of tergites III and IV (3). (4) 'Quedius' vividus (Broun, 1880): elytra and tergites III and IV. (5) 'Quedius' inaequalipennis Lea, 1925: tergites III, IV, and V. PR = Pronotum. Scale bars: $(\mathbf{1})=0.5 \mathrm{~mm},(\mathbf{2}-\mathbf{5})=1.0 \mathrm{~mm}$.

Legs not well preserved. Tibiae (presumably mesotibiae) with at least one spur apically (Fig. 1.2, SP). Tarsi (presumably mesotarsi) consisting of five tarsomeres (Fig. 1.2, $\mathrm{T} 1-\mathrm{T} 5)$

Etymology.-The specific epithet is the Māori verb meto, to become extinct.

Remarks. - The new species is tentatively assigned to the genus Sphingoquedius, however it is supported by several shared morphological characters. The recognition and definition of Sphingoquedius is likely to change in the future since the extant fauna of New Zealand Amblyopinini requires revision at the genus level.
Order Coleoptera Linnaeus, 1758

Family Staphylinindae Latreille, 1802

Subfamily Staphylininae Latreille, 1802

\section{Staphylininae incertae sedis}

Material.—OU45239. Female.

Remarks.-This is the specimen earlier referred to as a stonefly (Plectoptera, Austroperlidae) by Kaulfuss et al. (2015). After further preparation and imaging, it can now be identified as a female staphylinid due to the presence of distinct valvifers at the abdominal apex. This specimen could represent a second species of fossil amblyopinine, however preservation is too incomplete to be certain. 


\section{Discussion}

Systematic position of Sphingoquedius meto $n$. sp.-Sphingoquedius meto $\mathrm{n}$. sp. is undoubtedly a rove beetle (Staphylinidae) due to the distinctive elongate habitus and discernible morphological characters: antennae 11 segmented, short elytra with the abdomen exposed, and others. Although insufficient preservation does not allow observation of certain informative characters for sub-familial placement, the overall habitus, body proportions, slender antennae, abdomen with two pairs of paratergites, and long inflated apical portions of lateral tergal sclerites X suggest its placement in the subfamily Staphylininae. The overall habitus, the distinct isodiametric microsculpture on the pronotum, multidirectionally arranged setae on the elytra, and presence of patches of radiating setae on abdominal tergites (preserved only on the fourth abdominal tergite) provide strong evidence that the fossil belongs to the tribe Amblyopinini. This combination of characters, even the long inflated apical portions of the lateral tergal sclerites IX alone, also exclude its placement in the morphologically similar and related subfamily Paederinae, or in the sister, albeit generally more distinct, subfamily Xantholininae. The only other tribe of Staphylininae that could potentially exhibit such a combination of characters is Quediini, however our fossil can be excluded from Quediini due to the scutellum with anterior scutellar ridge only (anterior and posterior scutellar ridge present in Quediini and most other tribes of Staphylininae). Exclusion of Quediini is also supported by the restriction of the recent members of this tribe to the temperate zone of the Northern Hemisphere only. Quediines are absent in the Southern Hemisphere (except as human-assisted introductions), whereas Amblyopinini are the dominant staphylinine group in the recent temperate fauna of the Southern Hemisphere and New Zealand in particular. Considering that the New Zealand fauna of Ambiopinini requires complete generic revision, here we can only tentatively assign this fossil to the genus Sphingoquedius (also see Introduction) based on several morphological characters justifying such a placement. These are the rather large eyes and presence of patches of radiating setae on abdominal tergites (in the fossil preserved only on tergite IV) (Figs. 1.2, 2.3). The patches of radiating setae occur in several described and undescribed recent amblyopinines in New Zealand and its Subantarctic Islands. In New Zealand, such described species are for example ' $Q$.' aucklandicus Cameron, 1947, 'Q.' latifrons Sharp, 1886, 'Q.' latimanus Broun, 1893, and 'Q.' vividus (Broun, 1880) (Fig. 2.4), and 'Quedius' aliiceps Cameron, 1948 in the Subantarctic Islands (Auckland Island). The patches of radiating setae also occur in taxa from South America and Australia (e.g., 'Quedius' inaequalipennis Lea, 1925; Fig. 2.5). The multidirectionally arranged setae on the elytra also occur in several species of amblyopinines from around the tribe's distribution range, and in New Zealand in particular in 'Quedius' vividus. The isodiametric microsculpture on the pronotum is the most notable trait of the fossil because among all other free living Amblyopinini it occurs only in a very few recent species from New Zealand or its Subantarctic Islands: in 'Quedius' latimanus, 'Q.' aeneiventris Broun, 1910, one undescribed species from the Snares from New Zealand, and in ' $Q$.' aliiceps (Auckland Island) from the Subantarctic Islands. However, in 'Quedius' latimanus and 'Q.' aeneiventris, it is much less developed compared to the fossil, while in ' $Q$.' aliiceps it is combined with rough punctuation (absent in the fossil). From all mentioned recent species with the isodiametric microsculpture, Sphingoquedius meto $\mathrm{n}$. sp. obviously differs in various characters, including habitus. The specimen is tentatively identified as a male due to the apparent absence of valvifers, although this could be preservation bias. Based on our character assessment and knowledge of amblyopinine morphological diversity, Sphingoquedius meto $\mathrm{n}$. sp. is part of the clade that includes morphologically diverse, mostly New Zealand and some Australian taxa (Jenkins Shaw et al., 2020, p. 438, fig. 4, clade F3). Therefore, Sphingoquedius meto $\mathrm{n}$. sp. appears nested within a clade closer to the crown of the amblyopinine phylogeny diversity of the tribe. Detailed species- and genuslevel revision of the recent amblyopinine diversity and possible new findings of better-preserved fossils may help to place this species in a recent species group where, probably, such an unusual character as the isodiametric microsculpture on the pronotum exhibited by the fossil may play an important role.

Biogeography.-The fossil record of the rove beetle tribe Amblyopinini is very poor and homogenous, with only three fossils known so far, of which one is very doubtful (Table 1). The two Dominican amber fossils show a strong resemblance to the type and other species of Heterothops from North and South America. Interestingly, Heterothops is one of only two genera of Amblyopinini (the other being Ctenandropus Cameron, 1926) that have wide distributions, reaching the Northern Hemisphere, which is not typical in this tribe. Presumably they dispersed into the Northern Hemisphere (Jenkins Shaw et al., 2020). Those fossils are relevant for any research on the phylogeny and biogeography of Amblyopinini, especially with regards to understanding the origins of Heterothops in the Northern Hemisphere. But they are not informative for understanding the evolution of the core diversity of the tribe, which is confined to the south temperate areas of the globe.

Sphingoquedius meto $\mathrm{n}$. sp. is the first fossil with such potential. It is also the first Southern Hemisphere record of Amblyopinini, and the first fossil rove beetle to be described from New Zealand. With its earliest Miocene age, it represents the fauna after the partial (Cooper and Cooper, 1995) or complete (Landis et al., 2008) submergence of Zealandia in the late Oligocene at 25-23 Ma. Sedimentological and paleontological data (e.g., Lee et al., 2014; Mortimer and Strong, 2014) and recent reviews of molecular data (e.g., Wallis and Jorge, 2018) provide no support for complete inundation of land area, suggesting that at least some of the terrestrial biota survived the Oligocene maximum marine transgression. It is not the purpose of this paper to make a judgement on these issues, merely to note that our fossil could be informative in this respect. It is possible that Amblyopinini as a lineage may have persisted in New Zealand since its shared history with the rest of Gondwana (i.e., probably even predating the separation of New Zealand from Australia, ca. $80 \mathrm{Myr}$ ). Other Miocene insects from New Zealand also represent lineages that mainly diversified before the breakup of Gondwana and presumably persisted in New Zealand until the Miocene or to the present day, including termites (Engel and Kaulfuss, 2017), ants (Kaulfuss and 
Dlussky, 2015), and tettigarctid cicadas (Kaulfuss and Moulds, 2015). Alternatively, if the Amblyopinini lineage represented by Sphingoquedius meto $\mathrm{n}$. sp. colonized New Zealand by transoceanic dispersal in the Cenozoic, this must have happened in or before the earliest Miocene. Additionally, Sphingoquedius meto $\mathrm{n}$. sp. may be informative as a minimum-age fossil calibration point in any future phylogenetic studies seeking to elucidate the temporal evolution of the group in New Zealand and elsewhere.

Paleoecology.—Based on sedimentological and paleontological reconstructions, Foulden Maar was a $\sim 2 \mathrm{~km}$ diameter and $\sim 300$ $\mathrm{m}$ deep, hydrologically closed lake (Lindqvist and Lee, 2009; Kaulfuss, 2017). Surrounding the lake was a complex Lauraceae-dominated notophyll vine rainforest with diverse understory vegetation (Bannister et al., 2012), in contrast to regional Nothofagus Blume, 1851 and conifer-dominated forests growing at some distance from the lake (Lee et al., 2016). Documented foragers on the forest floor include ants, rove beetles, and other beetles (including Cerambycidae, Chrysomelidae, Curculionidae, and possibly Hydrophilidae) (Kaulfuss et al., 2015). Paleoclimate estimates suggest that the mean annual temperature was between $18^{\circ} \mathrm{C}$ and $21^{\circ} \mathrm{C}$, compared to current temperatures of between $6^{\circ} \mathrm{C}$ and $15^{\circ} \mathrm{C}$ (Lee et al., 2016). All amblyopinine rove beetles are active predators, particularly in the forest-floor leaf litter, debris, fungi, and even in the fur of mammals (Ashe and Timm, 1987; Solodovnikov and Jenkins Shaw, 2017). Presumably, as we can guess for many recent forest-associated New Zealand amblyopinines, Sphingoquedius meto $\mathrm{n}$. sp. was probably an active predator of small invertebrates in this rainforest environment, where it potentially coexisted with other as yet undiscovered amblyopinine taxa.

\section{Conclusions}

Description and systematic placement of fossil taxa contributes to the reconstruction of paleoenvironments and their associated ecology and biogeographical components. Here, we described the new species Sphingoquedius meto, the first beetle from the Foulden Maar fossil-Lagerstätte. It is from the tribe Amblyopinini, a group that dominates the Southern Hemisphere temperate forest leaf litter and other terrestrial habitats. The discovery of Sphingoquedius meto $\mathrm{n}$. sp. places a minimum age on the presence of amblyopinines in New Zealand at the earliest Miocene, although we suspect their evolutionary history in this biogeographically complex region significantly predates this age. The new species may represent an amblyopinine lineage associated with the Foulden paleo-rainforest that went extinct with cooling temperatures in or after the late Miocene. It is likely that more new species of amblyopinine and other rove beetles will be discovered from Foulden Maar and other emerging New Zealand fossil deposits in the future.

\section{Acknowledgments}

We wish to thank the Gibson family for allowing access to the fossil site, and D. Lee for coordinating paleontological research at Foulden Maar over many years. Research at Foulden Maar was supported by the Royal Society of New Zealand Marsden Fund (grant number UOO-11 15). This work was funded by a Chinese Academy of Sciences President's International Fellowship Initiative for Postdoctoral Fellows (Grant No. 2019PB0090) to JJS, German Research Foundation (project 429296833), National Natural Science Foundation of China (numbers 31672345, 31961143002), and GDAS Special Project of Science and Technology Development (No. 2020GDASYL20200102021, 2020GDASYL-20200301003).

\section{References}

Ashe, J.S., and Timm, R.M., 1987, Predation by and activity patterns of 'parasitic' beetles of the genus Amblyopinus (Coleoptera: Staphylinidae): Journal of Zoology, v. 212, p. 429-437.

Bannister, J.M., Conran, J.G., and Lee, D.E., 2012, Lauraceae from rainforest surrounding an early Miocene maar lake, Otago, southern New Zealand: Review of Palaeobotany and Palynology, v. 178, p. 13-34.

Bernhauer, M., 1941, Neue Staphyliniden aus Neu-Seeland (New Zealand): Folia Zoologica et Hydrobiologica, v. 11, p. 26-38.

Blume, C.L. von, 1851, Ord. Cupulifereae: Museum Botanicum LugdunoBatavum, v. 1, p. 305-320.

Broun, T., 1880, Manual of the New Zealand Coleoptera. Part 1: Wellington, James Hughes, 651 p.

Broun, T., 1893, Manual of the New Zealand Coleoptera. Parts V-VII: Wellington, Samuel Costall, p. 975-1504.

Broun, T., 1910, Descriptions of new genera and species of Coleoptera: New Zealand Institute Bulletin, v. 1, p. 1-78.

Brunke, A.J., Chatzimanolis, S., Schillhammer, H., and Solodovnikov, A., 2016, Early evolution of the hyperdiverse rove beetle tribe Staphylinini (Coleoptera: Staphylinidae: Staphylininae) and a revision of its higher classification: Cladistics, v. 32, p. 427-451.

Cai, C.Y., Yan, E.V., Beattie, R., Wang, B., and Huang, D.Y., 2013, First rove beetles from the Jurassic Talbragar fish bed of Australia (Coleoptera, Staphylinidae): Journal of Paleontology, v. 87, p. 650-656.

Cai, C., Beattie, R., and Huang, D., 2015, Jurassic olisthaerine rove beetles (Coleoptera: Staphylinidae): 165 million years of morphological and probably behavioral stasis: Gondwana Research, v. 28, p. 425-431.

Cai, C., Wang, Y., Liang, L., Yin, Z., Thayer, M.K., Newton, A.F., and Zhou, Y-L., 2019, Congruence of morphological and molecular phylogenies of the rove beetle subfamily Staphylininae (Coleoptera: Staphylinidae): Scientific Reports, v. 9, 15137.

Cameron, M., 1926, New species of Staphylinidae from India. Part II: Transactions of the Entomological Society of London, v. 73, p. 341-372.

Cameron, M., 1947, New species of Staphylinidae (Col.) from New Zealand: The Annals and Magazine of Natural History, v. 13, p. 701-710.

Cameron, M., 1948, New species of Staphylinidae (Col.) from New Zealand: The Annals and Magazine of Natural History, v. 14, p. 723-731.

Chatzimanolis, S., and Engel, M.S., 2013, The Fauna of Staphylininae in Dominican Amber (Coleoptera: Staphylinidae): Annals of Carnegie Museum, v. 81, p. 281-294.

Cooper, A., and Cooper, R.A., 1995, The Oligocene bottleneck and New Zealand biota: genetic record of a past environmental crisis: Proceedings of the Royal Society of London. Series B: Biological Sciences, v. 261, p. 293-302.

Duvivier, A., 1883, Énumération des Staphylinides, décrits depuis la publication du catalogue de M. M. Gemminger et de Harold: Annales de la Société Entomologique de Belgique, v. 27, p. 91-215.

Engel, M.S., and Kaulfuss, U., 2017, Diverse, primitive termites (Isoptera: Kalotermitidae, incertae sedis) from the early Miocene of New Zealand: Austral Entomology, v. 56, p. 94-103.

Fox, B.R.S., Wartho, J., Wilson, G.S., Lee, D.E., Nelson, F.E., and Kaulfuss, U., 2015, Long-term evolution of an Oligocene/Miocene maar lake from Otago, New Zealand: Geochemistry, Geophysics, Geosystems, v. 16, p. $59-76$.

Jenkins Shaw, J., Żyła, D., and Solodovnikov, A., 2020, Molecular phylogeny illuminates Amblyopinini (Coleoptera: Staphylinidae) rove beetles as a target for systematic and evolutionary research: Systematic Entomology, v. 45, p. $430-446$.

Kaulfuss, U., 2017, Crater stratigraphy and post-eruptive evolution of the Foulden Maar, southern New Zealand: New Zealand Journal of Geology and Geophysics, v. 60, p. 410-432.

Kaulfuss, U., and Dlussky, G.M., 2015, Early Miocene Formicidae (Amblyoponinae, Ectatomminae, ?Dolichoderinae, Formicinae and Ponerinae) from the 
Foulden Maar fossil lagerstätte, New Zealand, and their biogeographic relevance: Journal of Paleontology, v. 89, p. 1043-1055.

Kaulfuss, U., and Moulds, M., 2015, A new genus and species of tettigarctid cicada from the early Miocene of New Zealand: Paratettigarcta zealandica (Hemiptera, Auchenorrhyncha, Tettigarctidae): ZooKeys, v. 484, p. 83-94.

Kaulfuss, U., Lee, D.E., Barratt, B.I., Leschen, R.A., Larivière, M.C., Dlussky, G.M., Henderson, I.M., and Harris, A.C., 2015, A diverse fossil terrestrial arthropod fauna from New Zealand: evidence from the early Miocene Foulden Maar fossil lagerstätte: Lethaia, v. 48, p. 299-308.

Klimaszewski, J., Newton, A.F., and Thayer, M.K., 1996, A review of the New Zealand rove beetles (Coleoptera: Staphylinidae): New Zealand Journal of Zoology, v. 23, p. 143-160.

Landis, C.A., Campbell, H.J., Begg, J.G., Mildenhall, D.C., Paterson, A.M., and Trewick, S.A., 2008, The Waipounamu Erosion Surface: questioning the antiquity of the New Zealand land surface and terrestrial fauna and flora: Geological Magazine, v. 145, p. 173-197.

Latreille, P.A., 1802, Histoire naturelle, générale et particulière, des crustacés et des insectes. V. 3: Paris, F. Dufart, 467 p.

Lea, A.M., 1925, On Australian Staphylinidae (Coleoptera). Part II: Transactions and Proceedings of the Royal Society of South Australia, v. 49 p. 213-253.

Lee, D.E., Lindqvist, J.K., Beu, A.G., Robinson, J.H., Ayress, M.A. Morgans, H.E.G., and Stein, J.K., 2014, Geological setting and diverse fauna of a Late Oligocene rocky shore ecosystem, Cosy Dell, Southland: New Zealand Journal of Geology and Geophysics, v. 57, p. 195-208.

Lee, D. E., Kaulfuss, U., Conran, J. G., Bannister, J. M., and Lindqvist, J. K., 2016, Biodiversity and palaeoecology of Foulden Maar: an early Miocene Konservat-Lagerstätte deposit in southern New Zealand: Alcheringa: An Australasian Journal of Palaeontology, v. 40, p. 525-541.

Lindqvist, J.K., and Lee, D.E., 2009, High-frequency paleoclimate signals from Foulden Maar, Waipiata Volcanic Field, southern New Zealand: an Early Miocene varved lacustrine diatomite deposit: Sedimentary Geology, v. 222 , p. $98-110$.

Linnaeus, C., 1758, Systema naturae, per regna tria naturae, secundum Classes, Ordines, Genera, Species, cum characteribus, differentiis, synonymis, locis. V. 1: Holmiae, Laurentii Salvii, 824 p.

Mildenhall, D.C., Kennedy, E.M., Lee, D.E., Kaulfuss, U., Bannister, J.M., Fox, B., and Conran, J.G., 2014, Palynology of the early Miocene Foulden Maar, Otago, New Zealand: diversity following destruction: Review of Palaebotany and Palynology, v. 204, p. 27-42.

Mortimer, N., and Strong, D.T., 2014, New Zealand limestone purity: New Zealand Journal of Geology and Geophysics, v. 57, p. 209-218

Newton, A.F, 2019, StaphBase: Staphyliniformia world catalog database (v. November 2018), in Roskov, Y., Ower, G., Orrell, T., Nicolson, D., Bailly, N., Kirk, P.M., Bourgoin, T., DeWalt, R.E., Decock, W., Nieukerken, E. van, Zarucchi, J., Penev, L., eds., Species 2000 \& ITIS Catalogue of Life, 26th February 2019. Digital resource at www.catalogueoflife.org/col. Species 2000: Naturalis, Leiden, the Netherlands. ISSN 2405-8858. [Dec 2019].
Schneider, C.A., Rasband, W.S., and Eliceiri, K.W., 2012, NIH Image to ImageJ: 25 years of image analysis: Nature Methods, v. 9, p. 671-675.

Schomann, A., and Solodovnikov, A., 2012, A new genus of Staphylinidae (Coleoptera) from the Lower Cretaceous: the first fossil rove beetles from the Southern Hemisphere: Systematic Entomology, v. 37, p. 379-386.

Scudder, S.H., 1900, Adephagous and clavicorn Coleoptera from the Tertiary deposits at Florissant, Colorado with descriptions of a few other forms and a systematic list of the non-Rhynchophorous tertiary Coleoptera of North America: Monographs of the United States Geological Survey, v. 40, p. 9-143.

Seevers, C.H., 1944, Anew subfamily of beetles parasitic on mammals. Staphylinidae, Ambylopininae: Field Museum of Natural History, Zoological Series, v. 28, p. 153-172.

Sharp, D., 1886, On New Zealand Coleoptera, with descriptions of new genera and species: Scientific Transactions of the Royal Dublin Society, v. 3, p. $351-451$.

Solodovnikov, A. 2006, Revision and phylogenetic assessment of Afroquedius gen. nov. from South Africa: toward new concepts of the genus Quedius, subtribe Quediina and reclassification of the tribe Staphylinini (Coleoptera: Staphylinidae: Staphylinidae): Annals of the Entomological Society of America, v. 99, p. 1064-1084.

Solodovnikov, A., and Brunke, A., 2016, Cafioquedus gularis Sharp, 1886 and other poorly understood Staphylinini: a review of the New Zealand fauna of the tribe with discussion of its potential for biogeography (Insecta: Coleoptera: Staphylinidae): New Zealand Entomologist, v. 39, p. 40-61.

Solodovnikov, A., and Jenkins Shaw, J., 2017, The remarkable Australian rove beetle genus Myotyphlus: its cryptic diversity and significance for exploring mutualism among insects and mammals (Coleoptera: Staphylinidae): Austral Entomology, v. 56, p. 311-321.

Stephens, J.F., 1829, The Nomenclature of British Insects; being a compendious list of such species as are contained in the Systematic Catalogue of British Insects, and forming a guide to their classification: London, Baldwin and Cradock, $68 \mathrm{p}$.

Tihelka, E., Thayer, M.K., Newton, A.F., and Cai, C., 2020, New data, old story: molecular data illuminate the tribal relationships among rove beetles of the subfamily Staphylininae (Coleoptera: Staphylinidae): Insects, v. 11, 164. doi: 10.3390/insects11030164.

Wallis, G.P., and Jorge, F., 2018, Going under down under? Lineage ages argue for extensive survival of the Oligocene marine transgression on Zealandia: Molecular Ecology, v. 27, p. 4368-4396.

Żyła, D., and Solodovnikov, A., 2020, Multilocus phylogeny defines a new classification of Staphylininae (Coleoptera: Staphylinidae), a rove beetle group with high lineage diversity: Systematic Entomology, v. 45, p. 114-127.

Accepted: 11 May 2020 